Litors r r $\begin{array}{r}2018 \text { Volume 24(2): 670-695 } \\ \text { doi:10.3846/20294913.2016.1255275 }\end{array}$

\title{
AN INTEGRATED FUZZY AHP AND ARAS MODEL TO EVALUATE MOBILE BANKING SERVICES
}

\author{
Fatih ECER \\ Department of Business Administrative, Faculty of Economics and Administrative Sciences, ANS \\ Campus, Afyon Kocatepe University, Afyonkarahisar 03030, Turkey
}

Received 28 October 2015; accepted 27 October 2016

\begin{abstract}
Mobile banking (M-banking) which integrates software, hardware, and human is a new platform for banks. Determining the performance of M-banking services helps bank practitioners identify better policy to improve their positions. The aim of this study is to develop an integrated model for evaluating M-banking services by two methods, namely the Fuzzy Analytic Hierarchy Process (FAHP) with an extent analysis approach and ARAS (Additive Ratio ASsessment). In this study, the priority weights obtained through the FAHP are combined with the ARAS method to assess and rank the M-banking services. Moreover, in order to verify the applicability of this proposed model, a case study in Turkey is offered. The findings indicate that facilitating conditions play the most determining role in the adoption of the M-banking, followed by self-efficacy, privacy risk, and security risk. Consequently, the proposed model helps to overcome difficulties in M-banking service evaluation process and increases the efficiency of the M-banking service activities. Besides, the case study validates that the proposed model is an effective and efficient decision making tool for the evaluation of M-banking services under fuzzy environments.
\end{abstract}

Keywords: M-banking services, M-banking adoption, Fuzzy AHP, ARAS.

JEL Classification: C44, D81, M11.

\section{Introduction}

With the use of the right technological equipment and techniques, firms achieve their business goals more rapidly. In a globalizing and competitive industry, technological applications play an essential role in facilitating the processes of knowledge production, storage, sharing and application. Through these processes, it is possible to benefit from the opportunities arising from environmental changes. Nevertheless, just a technological infrastructure cannot guarantee the effectiveness of a knowledge management program. The solution

Corresponding author Fatih Ecer

E-mail: fecer@aku.edu.tr 
stems from the strategic integration between human and knowledge resources, technologies, organizational culture, and processes (Canzano, Grimaldi 2012).

Banking sector, one of the leading sectors utilizing internet and mobile technology, is consistently seeking for ways to use technology in order to reduce costs and take the lead of the competition, and for the clients, create more proper methods of banking. A great success story in this area is made by electronic banking (Peevers et al. 2008; Laukkanen 2007). There are four electronic banking channels: ATMs, touch-dial telephone banking, Internet banking, and mobile banking (M-banking). In spite of M-banking has a huge potential, its real potential does not used. M-banking is defined as "a channel through which customers interact with a bank through non-voice applications such as text- or WAP-based banking services using a mobile device, such as a mobile phone or personal digital assistant" (Hoehle et al. 2012; Zhou 2012). M-banking has different characteristics from other electronic banking channels such as ubiquity, flexibility, and mobility (Lin 2011). From the standpoint of clients, M-banking provides a suitable and efficient by means of managing finance facilities, connecting perfectly anytime and anywhere (Riivari 2005). Nevertheless, because of the virtuality and lack of control, M-banking contains more uncertainty and risk (Zhou 2012).

Turkey, as an emerging market, has seen some significant developments over the past decade within the context of M-banking. In 2004, M-banking was first presented in Turkey by Garanti Bankasi. Nowadays, one third of all mobile clients are registered to Garanti Mbanking. In 2007, another strong competitor, Isbank, also joined the competition. Isbank introduced Isbank M-banking in 2007 with "IsCep". According to Banks Association of Turkey (BAT) report covering 16 banks those supplying electronic banking services, the total number of registered customers that logged in at least once was 6.8 million and the total number of investment transactions performed by using M-banking services were 2.1 million with an amount of $\$ 7.6$ billion as of June 2015. Accordingly, the number of customers using M-banking has grown by $117 \%$ in the last year. In addition, the total number and the volume of financial transactions (excluding investment transactions) performed by using M-banking services, was 252.5 million and $\$ 12.8$ billion, respectively, in the second quarter of 2015 (BAT 2015).

In that M-banking is a gaining currency electronic banking channel to be offered by banks, evaluating their performances is crucial for bank owners, clients, shareholders, policy makers, and service providers. Determining the performance of M-banking services helps bank owners, policy makers, and service providers. Hence, this performance evaluation problem can be considered as a multiple-criteria decision making (MCDM) problem. Aggregating both quantitative and qualitative criteria in the evaluation process, analyzing complex problems, and participating decision makers actively in the decision making process are the main advantages of MCDM (Zavadskas et al. 2014). In reality, exact numbers may not always be sufficient to introduce the decision making process, since human perception, judgment, intuition, and preference remain uncertain and hard to gauge. Fuzzy Set Theory (FST) (Zadeh 1965) is a way of investigating ambiguous notions and mediates for representing vagueness (Chou, Cheng 2012; Chen, Wang 2009). It is similar to human 
reasoning process in its use of incomplete information and ambiguity to create decisions. It was especially designed for mathematical representation of uncertainty and ambiguity and allows useful instrument to struggle with the imprecision intrinsic to many problems. Since knowledge can be expressed in a more easily by using fuzzy sets, many decision problems can be significantly simplified. FST is applied to classes of data with boundaries which are not precisely defined. Hence, real-world problems can be solved more easily. Thereby, linguistic variables have a critical importance in the fuzzy logic applications (Kahraman et al. 2004). In this respect, the study aims to propose an integrated model that combines FAHP with an extent analysis approach and ARAS methods for evaluating and ranking the M-banking services. The AHP proposed by Saaty in 1980 is a well-known MCDM method and the FAHP method is a generalization of the AHP on fuzzy environment. The ARAS method is utilized to prioritize the alternatives. It is relatively simple but effective MCDM method. Further, it is desirable that the appropriate alternative should have the biggest ratio to the optimal solution (Zavadskas, Turskis 2010). In the present study, the FAHP method is employed for obtaining the priority weights of the criteria. Hence, ARAS is utilized to calculate the performance of M-banking services. The contributions of this study in extant literature are threefold. First, to date, there is no research to our knowledge which integrates FAHP and ARAS methods. Second, till date, the ARAS method has very limited applications in the economic field. Lastly, in particular, no study to the best of our knowledge has been studied in the area of evaluation of M-banking services previously. Accordingly, in this study, for the determination of the weights of the main factors and sub-factors, FAHP method is used since it is based on pairwise comparisons. Then, the weights obtained through the FAHP method are combined with the ARAS to assess and rank the M-banking services. Furthermore, in order to verify the usefulness of this proposed model, a case study of the $16 \mathrm{M}$-banking services in Turkey is offered. The findings of this study, therefore, can help banks for a clear picture of their M-banking services and then prioritize the strategies to thrive. To meet the objective, the remainder of this study is structured as follows: the next section reviews the M-banking and adoption factors while Section 2 describes the theoretical background of FAHP and ARAS methods. Next, Section 3 gives an illustrating example. The penultimate section presents discussion and limitations of this study. Finally, last section draws the conclusions and discusses topics for further research.

\section{M-banking adoption factors}

Recently, M-banking adoption has gained attention from researchers and there is an intense interest for adoption of the M-banking. The adoption factors of M-banking are concerned closely ease of use, access to the service from anywhere and anytime, safety and savings in time and exertion. Despite the advantages, mobile phone usage in banking facilities is not expected level. There seem to be some barriers that decelerate mobile phone usage in banking operations (Laukkanen 2007). Consequently, recent studies on M-banking adoption factors are listed in Table 1. 
Table 1. Recent studies on M-banking adoption

\begin{tabular}{|c|c|}
\hline Authors & Adoption factors \\
\hline $\begin{array}{l}\text { Luarn and Lin } \\
(2005)\end{array}$ & usefulness, convenience, credibility, self-efficacy, cost \\
\hline Laukkanen (2007) & efficiency, convenience, safety \\
\hline Lee et al. (2007) & perceived risk, perceived usefulness, trust \\
\hline $\begin{array}{l}\text { Laukkanen and } \\
\text { Cruz (2008) }\end{array}$ & usage, value, risk, tradition and image \\
\hline Kim et al. (2009) & relative benefits, trust, structural assurances \\
\hline Gu et al. (2009) & usefulness, convenience, trust \\
\hline Crabbe et al. (2009) & perceived credibility, facilitating conditions \\
\hline Püschel et al. (2010) & $\begin{array}{l}\text { compatibility, convenience, relative benefit, visibility, demonstrability, image, } \\
\text { triability, perceived behavioral control, facilitation condition, subjective } \\
\text { norm, testability, intention }\end{array}$ \\
\hline $\begin{array}{l}\text { Koenig-Lewis et al. } \\
(2010)\end{array}$ & compatibility, perceived usefulness, risk, trust, cost \\
\hline Cruz et al. (2010) & cost, risk, perceived advantage, complexity \\
\hline $\begin{array}{l}\text { Wessels and } \\
\text { Drennan }(2010)\end{array}$ & usefulness, risk, convenience, financial cost, compatibility \\
\hline Zhou et al. (2010) & $\begin{array}{l}\text { task characteristics, technology characteristics, convenience conditions, task } \\
\text { technology fit, performance expectancy, effort expectancy, social influence }\end{array}$ \\
\hline $\begin{array}{l}\text { Riquelme and Rios } \\
(2010)\end{array}$ & $\begin{array}{l}\text { intention, perceived relative advantage, perceived risk, social norms, } \\
\text { convenience, usefulness }\end{array}$ \\
\hline Singh et al. (2010) & usefulness, ease of use, subjective norms, self-efficacy, cost, safety, trust \\
\hline Lin $(2011)$ & $\begin{array}{l}\text { perceived advantage, ease of use, compatibility, competence, benevolence, } \\
\text { integrity }\end{array}$ \\
\hline Negash (2011) & $\begin{array}{l}\text { usefulness, convenience, enjoyment, network quality, security, privacy, trust, } \\
\text { awareness, regulation, compliance }\end{array}$ \\
\hline $\begin{array}{l}\text { Akturan and Tezcan } \\
(2012)\end{array}$ & risk, ease of use, usefulness, benefit \\
\hline Zhou (2012) & structural assurance, ubiquity, ease of use, personal innovativeness \\
\hline Chen (2013) & $\begin{array}{l}\text { advantage, concurrency, trialability, complexity, different risk types, attitude, } \\
\text { intention to use, brand image, brand awareness }\end{array}$ \\
\hline $\begin{array}{l}\text { Hanafizadeh et al. } \\
\text { (2014) }\end{array}$ & $\begin{array}{l}\text { usefulness, ease of use, the need for interaction, risk, cost, compatibility with } \\
\text { life style, credibility, trust }\end{array}$ \\
\hline Bidar et al. (2014) & $\begin{array}{l}\text { usefulness, ease of use, security, privacy, compatibility, social influence, } \\
\text { facilitating conditions, cost }\end{array}$ \\
\hline
\end{tabular}

\section{Methodology}

This study combines the FAHP method with the ARAS method to establish a new integrated fuzzy MCDM model to assess M-banking services. To achieve this, the FAHP method is utilized to process the fuzzy information from expert judgments to determine the priority weights. Then, the ARAS method is employed to show preference of the alternatives with regard to evaluation factors and determine the final rankings of the M-banking services. The methods are explained detailed in the following subsections. 


\subsection{The Fuzzy AHP (FAHP) method}

There are various approaches for determining weights, e.g., AHP, SWARA, expert method, eigenvalue method, entropy method, etc. As one of the most widely utilized MCDM techniques AHP is developed by Saaty (1980) to solve complex MCDM problems involving qualitative decisions (Ecer 2014). AHP analyzes hierarchical relations between different decision levels without considering interrelations among factors or alternatives (Aliakbari Nouri et al. 2015). Decision makers separate the decision process into sub-parts, i.e. goal, factors and alternatives. As soon as the hierarchical structures, decision makers decide the importance of each factor in pairwise comparison thanks to Saaty's 9-point scale. What is more, AHP is a subjective methodology where information and priority weights of factors can be obtained from decision makers' judgments (Calabrese et al. 2013; Das et al. 2012). The decision makers' thoughts and preferences are difficult to evaluate in crisp numbers. In other words, the traditional MCDM methods do not clarify human thinking exactly (Chou, Cheng 2012). In this study, therefore, FST and AHP are integrated into the FAHP model to deal with ambiguity. To achieve this, FAHP converts linguistic judgments in Triangular Fuzzy Numbers (TFNs). These matrices are thus handled to obtain the importance weights of the items and alternatives' ranking (Calabrese et al. 2013). Laarhoven and Pedrycz (1983) have first used FAHP by adapting the TFN of the FST (Bulut et al. 2012). Fuzzy sets and FAHP extent analysis method are as follows (Tavana et al. 2013; Aghdaie et al. 2013; Ecer 2015).

A fuzzy number is a special fuzzy set $M=\left\{\left(x, \mu_{M}(x)\right), x \in \mathfrak{R}\right\}$, where $x$ takes its values on the real line, $\mathfrak{R}:-\infty \leq x \leq \infty$ and $\mu_{M}(x)$ is a membership function in the closed interval $[0,1]$. TFNs are the most popular fuzzy numbers due to their simplicity and linearity of the triangular membership function and permitting rather simple implementation of the fuzzy arithmetical operations (Calabrese et al. 2016). A TFN represents each pair of elements in the same hierarchy, and can be denoted as $M=(l, m, u)$, where $l \leq m \leq u$. The parameters $l, m, u$ express the lower bound value, the peak or center, and the upper bound value respectively. A TFN $M$ can be described as in Eq. (1).

$$
\mu_{M}(x)=\left\{\begin{array}{ll}
0 & , x<l \\
(x-l) /(m-l) & , l \leq x \leq m \\
(u-x) /(u-m) & , m \leq x \leq u \\
0 & , x>u
\end{array} .\right.
$$

Consider two TFNs $M_{1}=\left(l_{1}, m_{1}, u_{1}\right)$ and $M_{2}=\left(l_{2}, m_{2}, u_{2}\right)$. The following describes fuzzy arithmetical operations:

$$
\begin{gathered}
\left(l_{1}, m_{1}, u_{1}\right) \oplus\left(l_{2}, m_{2}, u_{2}\right)=\left(l_{1}+l_{2}, m_{1}+m_{2}, u_{1}+u_{2}\right) ; \\
\left(l_{1}, m_{1}, u_{1}\right) \otimes\left(l_{2}, m_{2}, u_{2}\right) \approx\left(l_{1} l_{2}, m_{1} m_{2}, u_{1} u_{2}\right) ;
\end{gathered}
$$




$$
\left(l_{1}, m_{1}, u_{1}\right)^{-1} \approx\left(\frac{1}{u_{1}}, \frac{1}{m_{1}}, \frac{1}{l_{1}}\right) .
$$

Table 2 presents the fuzzy conversion utilized to transform the linguistic variables into membership functions.

Table 2. The fuzzy conversion

\begin{tabular}{lc}
\hline \multicolumn{1}{c}{ Definition } & Membership function \\
\hline Just equal & $(1.00,1.00,1.00)$ \\
\hline Between equal and moderate & $(1.00,2.00,3.00)$ \\
\hline Moderate importance & $(2.00,3.00,4.00)$ \\
\hline Between moderate and fairly strong & $(3.00,4.00,5.00)$ \\
\hline Fairly strong importance & $(4.00,5.00,6.00)$ \\
\hline Between fairly strong and very strong & $(5.00,6.00,7.00)$ \\
\hline Very strong importance & $(6.00,7.00,8.00)$ \\
\hline Between very strong and absolute & $(7.00,8.00,9.00)$ \\
\hline Absolute importance & $(8.00,9.00,9.00)$ \\
\hline Reciprocal: $M_{1}^{-1} \approx\left(\frac{1}{u_{1}}, \frac{1}{m_{1}}, \frac{1}{l_{1}}\right)$ & \\
\hline
\end{tabular}

Source: Chan and Kumar (2007)

The major criticism of Chang's extent analysis (1992) is that the weights derived by this method do not represent the priority weights of decision criteria or alternatives (Zhu et al. 1999; Leung, Cao 2000; Mikhailov 2003; Wang et al. 2008; Wang, Chin 2011). Despite the fact that some criticisms for Chang's extent analysis, the vast majority of the applications use it. Hence, the extent analysis is utilized due to its implementation simplicity to calculate importance weights in this study.

Let $X=\left\{x_{1}, x_{2}, \ldots, x_{n}\right\}$ be an object set, and $U=\left\{u_{1}, u_{2}, \ldots, u_{m}\right\}$ be a goal set. As to the extent analysis, each object is taken and extent analysis for each goal, $g_{i}$, is performed, respectively. Therefore, $m$ extent analysis values for each object can be obtained, with the following signs:

$$
M_{g_{i}}^{1}, M_{g_{i}}^{2}, \ldots, M_{g_{i}}^{m}, i=1,2, \ldots, n,
$$

where all the $M_{g_{i}}^{j}(j=1,2, \ldots, m)$ are TFNs. The steps of extent analysis can be given as follows (Chang 1996; Kahraman et al. 2004; Aghdaie et al. 2013):

Step 1: The value of fuzzy synthetic extent with respect to the $i$ th object is defined as

$$
S_{i}=\sum_{j=1}^{m} M_{g_{i}}^{j} \otimes\left[\sum_{i=1}^{n} \sum_{j=1}^{m} M_{g_{i}}^{j}\right]^{-1} .
$$

To obtain $\sum_{j=i}^{m} M_{g_{i}}^{j}$, perform the fuzzy addition operation of $m$ extent analysis values for a particular matrix such that: 


$$
\sum_{j=1}^{m} M_{g_{i}}^{j}=\left(\sum_{j=1}^{m} l_{j}, \sum_{j=1}^{m} m_{j}, \sum_{j=1}^{m} u_{j}\right)
$$

and to obtain $\left[\sum_{i=1}^{n} \sum_{j=1}^{m} M_{g_{i}}^{j}\right]^{-1}$ perform the fuzzy addition operation of $M_{g_{i}}^{j} \quad(j=1,2, \ldots, m)$ values such that:

$$
\sum_{i=1}^{n} \sum_{j=1}^{m} M_{g_{i}}^{j}=\left(\sum_{i=1}^{n} l_{i}, \sum_{i=1}^{n} m_{i}, \sum_{i=1}^{n} u_{i}\right)
$$

and then compute the inverse of the vector in Eq. (8) such that:

$$
\left[\sum_{i=1}^{n} \sum_{j=1}^{m} M_{g_{i}}^{j}\right]^{-1}=\left(\frac{1}{\sum_{i=1}^{n} u_{i}}, \frac{1}{\sum_{i=1}^{n} m_{i}}, \frac{1}{\sum_{i=1}^{n} l_{i}}\right) \text {. }
$$

Step 2: The degree of possibility of $M_{2}=\left(l_{2}, m_{2}, u_{2}\right) \geq M_{1}=\left(l_{1}, m_{1}, u_{1}\right)$ is defined as:

$$
V\left(M_{2} \geq M_{1}\right)=\sup _{y \geq x}\left[\min \left(\mu_{M_{1}}(x), \mu_{M_{2}}(y)\right],\right.
$$

and can be equivalently expressed as follows:

$$
V\left(M_{2} \geq M_{1}\right)=h g t\left(M_{1} \cap M_{2}\right)=\mu_{M_{2}}(d)=\left\{\begin{array}{l}
1, \text { if }\left(m_{2} \geq m_{1}\right), \\
0, \quad \text { if }\left(l_{1} \geq u_{2}\right), \\
\frac{l_{1}-u_{2}}{\left(m_{2}-u_{2}\right)-\left(m_{1}-l_{1}\right)}, \text { otherwise, }
\end{array}\right.
$$

where $d$ is the ordinate of the highest intersection point $D$ between $\mu_{M_{1}}(x)$ and $\mu_{M_{2}}(x)$ as shown in Figure 1. To compare $M_{1}$ and $M_{2}$ it is requires both the values of $V\left(M_{1} \geq M_{2}\right)$ and $V\left(M_{2} \geq M_{1}\right)$.

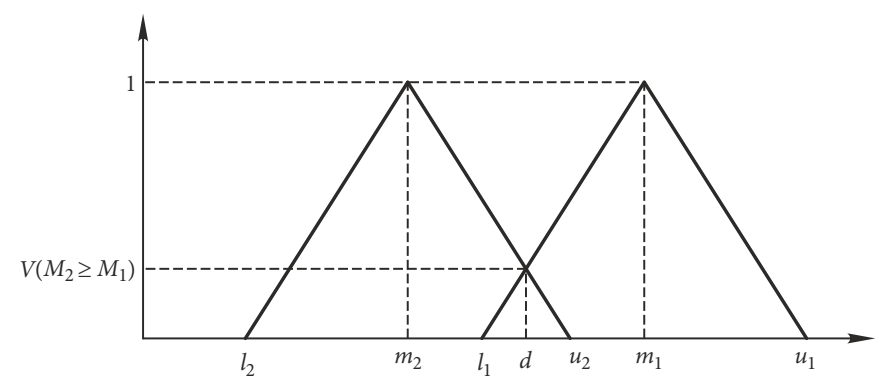

Fig. 1. The intersection between $M_{1}$ and $M_{2}$ Source: Aghdaie et al. 2013 
Step 3: The degree possibility for a convex fuzzy number to be greater than $k$ convex fuzzy numbers $M_{i}(i=1,2, \ldots, k)$ can be defined as:

$$
\begin{aligned}
& V\left(M \geq M_{1}, M_{2}, \ldots, M_{k}\right)=V\left[\left(M \geq M_{1}\right) \text { and }\left(M \geq M_{2}\right) \text { and } \ldots \text { and }\left(M \geq M_{k}\right)\right] \\
& =\min V\left(M \geq M_{i}\right), \quad i=1,2, \ldots, k .
\end{aligned}
$$

Assume that:

$$
d^{\prime}\left(A_{1}\right)=\min V\left(S_{i} \geq S_{k}\right) .
$$

For $k=1,2, \ldots, n ; k \neq i$. Then the weight vector is given by:

$$
W^{\prime}=\left(d^{\prime}\left(A_{1}\right), d^{\prime}\left(A_{2}\right), \ldots, d^{\prime}\left(A_{n}\right)\right)^{T},
$$

where $A_{i}(i=1,2, \ldots, n)$ are $n$ elements.

Step 4: Via normalization, the normalized weight vectors are:

$$
W=\left(d\left(A_{1}\right), d\left(A_{2}\right), \ldots, d\left(A_{n}\right)\right)^{T},
$$

where $W$ is a non-fuzzy number.

\subsection{The ARAS method}

MCDM is frequently used in the sciences and business and can improve the quality of decisions more explicit, rational, and efficient (Zavadskas et al. 2010).

A MCDM problem is closely related to the task of ranking decision alternatives (Dadelo et al. 2012). In this paper, the ARAS method is selected to rank alternatives. The ARAS method is based on simple relative comparisons. Decision criteria describe the optimal alternative (Kutut et al. 2013). In other words, the ARAS method gives a ratio of each alternative to the ideal alternative. In ARAS method, a utility function value is directly proportional to the weights of the main criteria and relative impact of alternatives (Zavadskas et al. 2010). It proposes to compare the ratios of utility function's scores of investigating alternatives with an optimal alternative utility function's score. For example, if an optimal score of criterion is 10 points, but among alternatives the biggest score of the criterion is 8 . Therefore, it is clear that the optimality level of criterion is 0.8 but not 1.0. Among MCDM methods, the ARAS method would be the most important candidate to make an objective ranking (Sliogeriene et al. 2013). According to Zamani et al. (2014), the ARAS method has several advantages: (i) the computations are comprehensible, (ii) the concepts are rather logical, (iii) simple, and (iv) the priority weights are obtained by comparisons. Hence, the ARAS method is used in this study because of its applicability for different decision making problems successfully, because of its simplicity algorithm, and because of its decision methodology which is based on comparison to the optimal alternative.

In recent years, the ARAS method has been implemented to the solution of complicated MCDM problems. Prior studies based on the ARAS method are listed in Table 3. 
Table 3. Recent studies based on the ARAS method

\begin{tabular}{ll}
\hline \multicolumn{1}{c}{ Authors } & \multicolumn{1}{c}{ Objective } \\
\hline Tupenaite et al. (2010) & Assessing cultural heritage renovation projects \\
\hline Zavadskas et al. (2010) & Selecting the foundation instalment alternative \\
\hline Zavadskas and Turskis (2010) & The evaluation of microclimate in office rooms \\
\hline Bakshi and Sarkar (2011) & Selecting the best project \\
\hline Sušinskas et al. (2011) & Selecting the pile-columns instalment alternative \\
\hline Zavadskas et al. (2012) & Assessing project managers in construction \\
\hline Dadelo et al. (2012) & Personnel assessment and ranking \\
\hline Baležentis et al. (2012) & Assessing Lithuanian economic sectors \\
\hline Sliogeriene et al. (2013) & Analyzing energy generation technologies \\
\hline Kutut et al. (2013) & Assessing preservation of historical buildings \\
\hline Reza and Majid (2013) & Ranking financial institutions \\
\hline Chatterjee and Chakraborty (2013) & Selecting material \\
\hline Baležentis and Štreimikiené (2013) & $\begin{array}{l}\text { Evaluating the progress achieved in implementing } \\
\text { sustainable development priorities }\end{array}$ \\
\hline Medineckiene et al. (2015) & Selecting criteria for building sustainability assessment \\
\hline Ecer (2016) & The evaluation of ERP software alternatives \\
\hline
\end{tabular}

The procedure of the ARAS method consists of the following steps (Zavadskas, Turskis 2010):

Step 1: Establish decision making matrix.

The following decision making matrix is constructed.

$$
X=\left[\begin{array}{cccc}
x_{01} & x_{02} & \cdots & x_{0 n} \\
x_{11} & x_{12} & \cdots & x_{1 n} \\
\vdots & \vdots & \cdots & \vdots \\
x_{m 1} & x_{m 2} & \cdots & x_{m n}
\end{array}\right] ; i=0,1, \ldots, m ; j=1,2, \ldots, n,
$$

where $m$ - number of alternatives, $n$ - number of criteria describing each alternative, $x_{i j}-$ value representing the performance value of the $i$ alternative in terms of the $j$ criterion, $x_{0 j}$ - optimal value of $j$ criterion. If optimal value of $j$ criterion is unknown, then:

$$
\left\{\begin{array}{lll}
\max _{i} x_{i j}, & \text { if } \max _{i} x_{i j} \text { is preferable } \\
\min _{i} x_{i j}^{*}, & \text { if } & \min _{i} x_{i j}^{*} \text { is preferable }
\end{array} .\right.
$$

Step 2: Construct normalized decision making matrix.

In the second step, decision making matrix is normalized:

$$
\bar{X}=\left[\begin{array}{cccc}
\bar{x}_{01} & \bar{x}_{02} & \cdots & \bar{x}_{0 n} \\
\bar{x}_{11} & \bar{x}_{12} & \cdots & \bar{x}_{1 n} \\
\vdots & \vdots & \cdots & \vdots \\
\bar{x}_{m 1} & \bar{x}_{m 2} & \cdots & \bar{x}_{m n}
\end{array}\right] ; i=0,1, \ldots, m ; j=1,2, \ldots, n .
$$


The criteria, whose preferable values are maxima, are normalized as follows:

$$
\bar{x}_{i j}=\frac{x_{i j}}{\sum_{i=0}^{m} x_{i j}} .
$$

The criteria, whose preferable values are minima, are normalized as follows:

$$
\bar{x}_{i j}=\frac{1 / x_{i j}}{\sum_{i=0}^{m} 1 / x_{i j}} .
$$

Step 3: Calculate weighted normalized matrix.

The third stage is defining normalized-weighted matrix $-\hat{X}$.

$$
\hat{X}=\left[\begin{array}{cccc}
\hat{x}_{01} & \hat{x}_{02} & \cdots & \hat{x}_{0 n} \\
\hat{x}_{11} & \hat{x}_{12} & \cdots & \hat{x}_{1 n} \\
\vdots & \vdots & \cdots & \vdots \\
\hat{x}_{m 1} & \hat{x}_{m 2} & \cdots & \hat{x}_{m n}
\end{array}\right] ; i=0,1, \ldots, m ; j=1,2, \ldots, n .
$$

Normalized-weighted values of all the criteria are calculated as follows:

$$
\hat{x}_{i j}=\bar{x}_{i j} w_{j} ; i=0,1, \ldots, m,
$$

where $w_{j}$ is the weight (importance) of the $j$ criterion and $\bar{x}_{i j}$ is the normalized rating of the $j$ criterion.

Step 4: Determine values of optimality function $S_{i}$ :

$$
S_{i}=\sum_{j=1}^{n} \hat{x}_{i j} ; i=0,1, \ldots, m \text {. }
$$

The bigger the value of the $S_{i}$, the more efficient the alternative.

Step 5: Calculate final ranking.

The utility degree $K_{i}$ of an alternative $a_{i}$ is calculated as follows:

$$
K_{i}=\frac{S_{i}}{S_{0}} ; i=0,1, \ldots, m,
$$

where $S_{i}$ and $S_{0}$ are the optimality criterion values.

$K_{i}$ values are in the interval $[0,1]$ and can be ordered in an increasing sequence, which is the wanted order of precedence.

\section{Proposed model for M-banking services evaluation}

In literature, there are many different MCDM techniques. The selection of appropriate decision making technique depends on the purpose of the problem, obtainable information, costs of decision, and decision makers' qualification. In this study, two of MCDM techniques are applied: ARAS and FAHP.

In the present study, $16 \mathrm{M}$-banking services in Turkey have been selected as a case study. That is to say, the whole M-banking services in Turkey are determined as the alternatives 
of the model. These are Akbank, Aktif Yatirim Bankasi, Denizbank, Finansbank, Garanti Bankasi, Halk Bankasi, HSBC, ING, Is Bankasi, Odea Bank, Sekerbank, Sinai Kalkinma Bankasi, TEB, Vakiflar Bankasi, Yapi Kredi Bankasi, and Ziraat Bankasi.

The proposed model can be divided into three sub-sections: (i) decision making team working, (ii) weighing the determined factors and sub-factors via the FAHP, and (iii) ranking the alternatives via the ARAS. Figure 2 demonstrates the schematic diagram of the proposed model.

The following subsection shows how to evaluate M-banking services in Turkey using the proposed model.

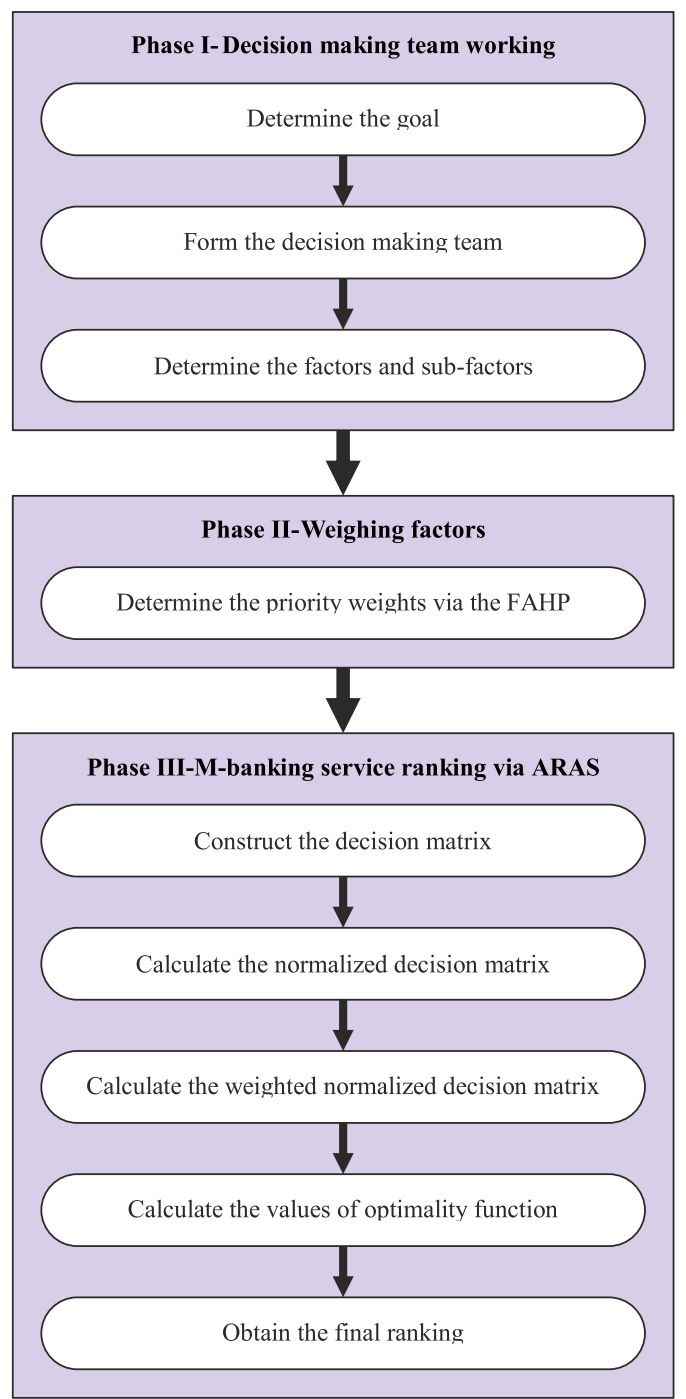

Fig. 2. The proposed integrated fuzzy model 


\subsection{Decision making team working}

This step is rather important for any banking evaluation problem. According to Zamani et al. (2014) and Bilsel et al. (2006), using a group of expert opinions are generally better than a single person to avoid prejudice to minimize the partiality in the case of complex problems.

Nowadays, managers often work in teams to make decisions because the complexity and ambiguity of the issues with which they must grapple can overwhelm the capacities of any one individual. A team's decision-making effectiveness depends in part upon its members' cooperativeness in providing information and in fully airing differences in assumptions and interpretations. What is more having input into a decision makes people feel the decision maker and affirms their status in the decision making team (Korsgaard et al. 1995). In order to determine and assess the factors affecting M-banking adoption, a decision making team including four practitioners (clients) and two experts having more than five years experience in the banking sector is constructed. Information about decision making team members is shown in Table 4. According to Table 4, most of the respondents are female. Moreover, the majority of the respondents falls into the 36-46 year-old age group. Finally, all respondents complete at least a bachelor.

Table 4. Demographic characteristics of decision making team members

\begin{tabular}{cc}
\hline Demographics & Frequency \\
\hline Gender & 2 \\
\hline Male & 4 \\
\hline Female & 2 \\
\hline Age & 3 \\
\hline $25-35$ & 1 \\
\hline $36-46$ & 3 \\
\hline Over 47 & 2 \\
\hline Education & 1 \\
\hline Bachelor & \\
\hline Master & \\
\hline PhD & \\
\hline
\end{tabular}

Many researchers have examined M-banking from the perspectives of TAM. Thereby, M-banking client adoption will be trying to explain based on user perceptions of the technology in this study. In accordance with the M-banking adoption factors, this study evaluates M-banking services from the perspectives of perceived usefulness, perceived ease of use, and perceived risk. In this context, In Table 5, factors and sub-factors considered in this study are given with their definitions. Those factors are collected from the earlier studies mentioned Section 2 under the supervision of the decision making team. Hence, the hierarchy of the model includes 3 factors and 8 sub-factors. 
Table 5. M-banking adoption factors as evaluation criteria

\begin{tabular}{|c|c|c|c|}
\hline Criteria & Sub-criteria & Definition & Goal \\
\hline \multirow{3}{*}{$\begin{array}{l}\text { Perceived } \\
\text { usefulness } \\
\text { (PUS) }\end{array}$} & & $\begin{array}{l}\text { When a person uses a particular system, it could enhance } \\
\text { his/her job performance (Davis 1989). The more useful } \\
\text { M-banking is, the more it will be used. }\end{array}$ & Maximum \\
\hline & $\begin{array}{l}\text { Social } \\
\text { influence (SI) }\end{array}$ & $\begin{array}{l}\text { Fishbein and Ajzen (1975) and Gu et al. (2009) define } \\
\text { social influence as "A person's perception that most people } \\
\text { who are import to him think he should or should not } \\
\text { perform the behavior in question". }\end{array}$ & Maximum \\
\hline & $\begin{array}{l}\text { System } \\
\text { quality (SQ) }\end{array}$ & $\begin{array}{l}\text { DeLone and McLean (2003) and Gu et al. (2009) state } \\
\text { that "Perceived network speed and system stability. System } \\
\text { quality affects intention and client satisfaction. Clients } \\
\text { will perceive it to be useful if the M-banking services are } \\
\text { provided accurately and with high speed". }\end{array}$ & Maximum \\
\hline \multirow{4}{*}{$\begin{array}{l}\text { Perceived } \\
\text { ease of use } \\
\text { (PEU) }\end{array}$} & & $\begin{array}{l}\text { According to Davis (1989), PEU means "The degree to } \\
\text { which the prospective user expects the target system to be } \\
\text { free of effort". The easier M-banking is, the more it will be } \\
\text { used. }\end{array}$ & Maximum \\
\hline & $\begin{array}{l}\text { Self-efficacy } \\
\text { (SE) }\end{array}$ & $\begin{array}{l}\text { Gu et al. (2009) and Venkatesh (2000) define SE as "A } \\
\text { belief that an individual has the capabilities to execute the } \\
\text { particular behavior with information technology (IT)". }\end{array}$ & Maximum \\
\hline & $\begin{array}{l}\text { Facilitating } \\
\text { conditions } \\
\text { (FC) }\end{array}$ & $\begin{array}{l}\text { Lu et al. (2003) and Gu et al. (2009) define FC as "The } \\
\text { external environments of helping clients overcome } \\
\text { barriers and hurdles to use a new IT. Clients will perceive } \\
\text { M-banking service to be easy to use when they recognize } \\
\text { that there are environmental conditions to help them learn } \\
\text { how to use M-banking service, although they cannot use } \\
\text { it skillfully". }\end{array}$ & Maximum \\
\hline & $\begin{array}{l}\text { Familiarity } \\
(\mathrm{FM})\end{array}$ & $\begin{array}{l}\text { Gu et al. (2009) defines FM as "An understanding, often } \\
\text { based on previous interactions, experiences, and learning } \\
\text { of what, why, where and when others do what they do". }\end{array}$ & Maximum \\
\hline \multirow{4}{*}{$\begin{array}{l}\text { Perceived } \\
\text { risk (PRI) }\end{array}$} & & $\begin{array}{l}\text { Chen (2013) defines PRI as "A perception about implicit } \\
\text { risk in using the open internet infrastructure to exchange } \\
\text { private information and it is often operationalized as a } \\
\text { multi-dimensional construct". }\end{array}$ & Minimum \\
\hline & $\begin{array}{l}\text { Privacy risk } \\
(\mathrm{PR})\end{array}$ & $\begin{array}{l}\text { Akturan and Tezcan (2012) defines PR as "Potential loss of } \\
\text { control over personal information". }\end{array}$ & Minimum \\
\hline & $\begin{array}{l}\text { Performance } \\
\text { risk (PF) }\end{array}$ & $\begin{array}{l}\text { Akturan and Tezcan (2012) defines PF as "The possibility } \\
\text { of the product malfunctioning". }\end{array}$ & Minimum \\
\hline & $\begin{array}{l}\text { Security risk } \\
\text { (SR) }\end{array}$ & $\begin{array}{l}\text { Akturan and Tezcan (2012) defines SR as "Potential loss of } \\
\text { control over transactions and financial information". }\end{array}$ & Minimum \\
\hline
\end{tabular}

Eventually, optimization directions of evaluation factors as follows:

$$
\begin{aligned}
& -S I, S Q, S E, F C, F M \stackrel{\text { optimization direction }}{\longrightarrow} \max ; \\
& -P R, P F, S R \stackrel{\text { optimization direction }}{\longrightarrow} \min .
\end{aligned}
$$




\subsection{Weighing factors}

First of all, the pairwise comparison matrix of three main factors and eight sub-factors are constructed to get their priority weight over another. Then, the fuzzy values are converted to crisp numbers by the Chang's extent analysis. The following tables (Tables 6-9) show the fuzzy evaluation of the factors. In order to achieve this, fuzzy synthetic extent values and the degree of synthetic extent values are calculated. Then, the weight vector is normalized defined as Eq. (15). After normalizing weight vector, the obtained priority weight vector of factors is figured out in the last column of Tables 6-9.

Table 6. Fuzzy evaluation of the main factors

\begin{tabular}{ccccc}
\hline & PUS & PEU & PRI & Priority weight \\
\hline PUS & $(1,1,1)$ & $(1 / 4,1 / 3,1 / 2)$ & $(1 / 3,1 / 2,1)$ & 0.0771 \\
\hline PEU & $(2,3,4)$ & $(1,1,1)$ & $(1,2,3)$ & 0.5665 \\
\hline PRI & $(1,2,3)$ & $(1 / 3,1 / 2,1)$ & $(1,1,1)$ & 0.3564 \\
\hline
\end{tabular}

Notes: $V\left(S_{P U S} \geq S_{P E U}\right)=0.14, V\left(S_{P E U} \geq S_{P U S}\right)=1.00, V\left(S_{P U S} \geq S_{P R I}\right)=0.53, V\left(S_{P R I} \geq S_{P U S}\right)=1.00$, $V\left(S_{P E U} \geq S_{P R I}\right)=1.00, V\left(S_{P R I} \geq S_{P E U}\right)=0.63$.

Table 7. Fuzzy evaluation of sub-factors as to perceived usefulness (PUS)

\begin{tabular}{cccc}
\hline & SI & SQ & Priority weight \\
\hline SI & $(1,1,1)$ & $(1 / 3,1 / 2,1)$ & 0.3080 \\
\hline SQ & $(1,2,3)$ & $(1,1,1)$ & 0.6920 \\
\hline
\end{tabular}

Notes: $V\left(S_{S I} \geq S_{S Q}\right)=0.45, V\left(S_{S Q} \geq S_{S I}\right)=1.00$.

Table 8. Fuzzy evaluation of sub-factors as to perceived ease of uhse (PEU)

\begin{tabular}{ccccc}
\hline & SE & FC & FM & Priority weight \\
\hline SE & $(1,1,1)$ & $(1 / 3,1 / 2,1)$ & $(1,2,3)$ & 0.3564 \\
\hline FC & $(1,2,3)$ & $(1,1,1)$ & $(2,3,4)$ & 0.5665 \\
\hline FM & $(1 / 3,1 / 2,1)$ & $(1 / 4,1 / 3,1 / 2)$ & $(1,1,1)$ & 0.0771 \\
\hline
\end{tabular}

Notes: $V\left(S_{S E} \geq S_{F C}\right)=0.63, V\left(S_{F C} \geq S_{S E}\right)=1.00, V\left(S_{S E} \geq S_{F M}\right)=1.00, V\left(S_{F M} \geq S_{S E}\right)=0.53$, $V\left(S_{F M} \geq S_{F C}\right)=0.14, V\left(S_{F C} \geq S_{F M}\right)=1.00$.

Table 9. Fuzzy evaluation of sub-factors as to perceived risk (PRI)

\begin{tabular}{lllll}
\hline & PR & PF & SR & Priority weight \\
\hline PR & $(1,1,1)$ & $(1,2,3)$ & $(1,1,1)$ & 0.4089 \\
\hline PF & $(1 / 3,1 / 2,1)$ & $(1,1,1)$ & $(1 / 3,1 / 2,1)$ & 0.1822 \\
\hline SR & $(1,1,1)$ & $(1,2,3)$ & $(1,1,1)$ & 0.4089 \\
\hline
\end{tabular}

Notes: $V\left(S_{P R} \geq S_{P F}\right)=1.00, V\left(S_{P F} \geq S_{P R}\right)=0.45, V\left(S_{S R} \geq S_{P F}\right)=1.00, V\left(S_{P F} \geq S_{S R}\right)=0.45$, $V\left(S_{S R} \geq S_{P R}\right)=1.00, V\left(S_{P R} \geq S_{S R}\right)=1.00$. 


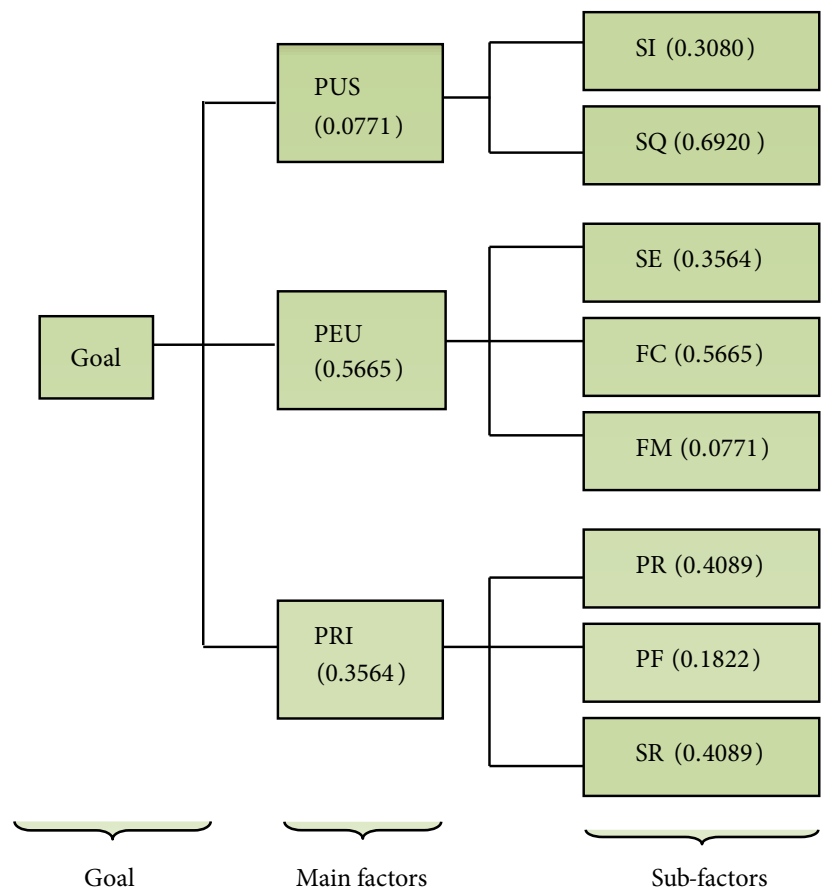

Fig. 3. Priority weights of main factors and sub-factors

Hence, Figure 3 shows a graphical plot of the weights. The final priority weights of eight sub-factors, therefore, SI, SQ, SE, FC, FM, PR, PF, and SR become 0.0237, 0.0534, 0.2019, $0.3209,0.0437,0.1457,0.065$, and 0.1457 respectively. As a result, FC, SE, PR, and SR are the top M-banking adoption factors. SI, however, has the lowest importance weight of 0.0237. The priority weights will be utilized in ARAS method.

\subsection{M-banking service ranking via the ARAS method}

The decision making matrix is built during this stage related to the evaluation of M-banking services. In this respect, $16 \mathrm{M}$-banking services in Turkey are selected as a case study. Moreover, $8 \mathrm{M}$-banking adoption factors characterizing these alternatives are determined. According to the algorithm of the ARAS method mentioned in Section 3, the problem is solved and the results are presented in Tables 10-13.

Initial decision making matrix (Table 10) contains an evaluation of the alternatives, factor values, and priority weights. According to Table 10, it could be stated that four adoption factors "Facilitating Conditions", "Self-efficacy", "Privacy Risk" and "Security Risk" have the maximum priority weight. After this, the initial decision making matrix is normalized as discussed in Section 3. The normalized decision making matrix is presented in Table 12. Then, the weighted decision making matrix presented in Table 12 is constructed. It follows the procedure described earlier and determines optimality function $\left(S_{i}\right)$ each alternative using Eq. (23). Finally, the utility degree of each alternative $\left(K_{i}\right)$ is determined using Eq. (24). 
Table 10. Determined initial data for analysis (initial decision making matrix)

\begin{tabular}{lcccccccc}
\hline & \multicolumn{7}{c}{ M-banking adoption factors } \\
\hline & SI & SQ & SE & FC & FM & PR & PF & SR \\
\hline Optimum direction & $x_{1}$ & $x_{2}$ & $x_{3}$ & $x_{4}$ & $x_{5}$ & $x_{6}$ & $x_{7}$ & $x_{8}$ \\
\hline Priority weights & 0.0237 & 0.0533 & 0.2019 & 0.3209 & 0.0432 & 0.1457 & 0.0656 & 0.1457 \\
\hline$a_{0}$ (optimal values) & 100 & 100 & 100 & 100 & 100 & 1 & 1 & 1 \\
\hline Akbank $\left(a_{1}\right)$ & 97 & 100 & 100 & 100 & 95 & 1 & 4 & 3 \\
\hline Aktif Yatirim Bankasi $\left(a_{2}\right)$ & 62 & 57 & 58 & 57 & 57 & 32 & 33 & 35 \\
\hline Denizbank $\left(a_{3}\right)$ & 55 & 49 & 49 & 50 & 46 & 40 & 41 & 42 \\
\hline Finansbank $\left(a_{4}\right)$ & 84 & 80 & 82 & 83 & 81 & 12 & 15 & 12 \\
\hline Garanti Bankasi $\left(a_{5}\right)$ & 89 & 85 & 95 & 91 & 87 & 7 & 8 & 7 \\
\hline Halk Bankasi $\left(a_{6}\right)$ & 79 & 77 & 78 & 77 & 76 & 15 & 19 & 15 \\
\hline HSBC $\left(a_{7}\right)$ & 57 & 54 & 52 & 50 & 49 & 37 & 37 & 41 \\
\hline ING $\left(a_{8}\right)$ & 95 & 92 & 95 & 98 & 92 & 3 & 4 & 3 \\
\hline Is Bankasi $\left(a_{9}\right)$ & 88 & 87 & 85 & 86 & 85 & 9 & 11 & 9 \\
\hline Odea Bank $\left(a_{10}\right)$ & 67 & 62 & 62 & 62 & 61 & 29 & 30 & 30 \\
\hline Sekerbank $\left(a_{11}\right)$ & 81 & 77 & 80 & 81 & 78 & 13 & 17 & 14 \\
\hline Sinai Kalkinma Bankasi $\left(a_{12}\right)$ & 71 & 67 & 68 & 69 & 66 & 24 & 27 & 25 \\
\hline TEB $\left(a_{13}\right)$ & 95 & 90 & 93 & 93 & 92 & 5 & 6 & 4 \\
\hline Vakiflar Bankasi $\left(a_{14}\right)$ & 75 & 71 & 72 & 74 & 72 & 20 & 24 & 21 \\
\hline Yapi Kredi Bankasi $\left(a_{15}\right)$ & 96 & 91 & 96 & 97 & 96 & 2 & 4 & 1 \\
\hline Ziraat Bankasi $\left(a_{16}\right)$ & 59 & 54 & 55 & 54 & 52 & 35 & 36 & 38 \\
\hline & & & & & & & & max \\
\hline
\end{tabular}

Table 11. Changed initial data for analysis (initial decision making matrix)

\begin{tabular}{lcccccccc}
\hline & \multicolumn{7}{c}{ M-banking adoption factors } \\
\hline & SI & SQ & SE & FC & FM & PR & PF & SR \\
\hline Optimum direction & $x_{1}$ & $x_{2}$ & $x_{3}$ & $x_{4}$ & $x_{5}$ & $x_{6}$ & $x_{7}$ & $x_{8}$ \\
\hline Priority weights & max & $\max$ & $\max$ & $\max$ & $\max$ & $\min$ & min & min \\
\hline$a_{0}$ (optimal values) & 100 & 100 & 100 & 100 & 100 & 1 & 1 & 1 \\
\hline Akbank $\left(a_{1}\right)$ & 97 & 100 & 100 & 100 & 95 & 1.000 & 0.250 & 0.333 \\
\hline Aktif Yatirim Bankasi $\left(a_{2}\right)$ & 62 & 57 & 58 & 57 & 57 & 0.031 & 0.030 & 0.029 \\
\hline Denizbank $\left(a_{3}\right)$ & 55 & 49 & 49 & 50 & 46 & 0.025 & 0.024 & 0.024 \\
\hline Finansbank $\left(a_{4}\right)$ & 84 & 80 & 82 & 83 & 81 & 0.083 & 0.067 & 0.083 \\
\hline Garanti Bankasi $\left(a_{5}\right)$ & 89 & 85 & 95 & 91 & 87 & 0.143 & 0.125 & 0.143 \\
\hline Halk Bankasi $\left(a_{6}\right)$ & 79 & 77 & 78 & 77 & 76 & 0.067 & 0.053 & 0.067 \\
\hline HSBC $\left(a_{7}\right)$ & 57 & 54 & 52 & 50 & 49 & 0.027 & 0.027 & 0.024 \\
\hline ING $\left(a_{8}\right)$ & 95 & 92 & 95 & 98 & 92 & 0.333 & 0.250 & 0.333 \\
\hline Is Bankasi $\left(a_{9}\right)$ & 88 & 87 & 85 & 86 & 85 & 0.111 & 0.091 & 0.111 \\
\hline
\end{tabular}


End of Table 11

\begin{tabular}{lcccccccc}
\hline & \multicolumn{7}{c}{ M-banking adoption factors } \\
\hline & SI & SQ & SE & FC & FM & PR & PF & SR \\
\hline & $x_{1}$ & $x_{2}$ & $x_{3}$ & $x_{4}$ & $x_{5}$ & $x_{6}$ & $x_{7}$ & $x_{8}$ \\
\hline Odea Bank $\left(a_{10}\right)$ & 67 & 62 & 62 & 62 & 61 & 0.034 & 0.033 & 0.033 \\
\hline Sekerbank $\left(a_{11}\right)$ & 81 & 77 & 80 & 81 & 78 & 0.077 & 0.059 & 0.071 \\
\hline Sinai Kalkinma Bankasi $\left(a_{12}\right)$ & 71 & 67 & 68 & 69 & 66 & 0.042 & 0.037 & 0.040 \\
\hline TEB $\left(a_{13}\right)$ & 95 & 90 & 93 & 93 & 92 & 0.200 & 0.167 & 0.250 \\
\hline Vakiflar Bankasi $\left(a_{14}\right)$ & 75 & 71 & 72 & 74 & 72 & 0.050 & 0.042 & 0.048 \\
\hline Yapi Kredi Bankasi $\left(a_{15}\right)$ & 96 & 91 & 96 & 97 & 96 & 0.500 & 0.250 & 1.000 \\
\hline Ziraat Bankasi $\left(a_{16}\right)$ & 59 & 54 & 55 & 54 & 52 & 0.029 & 0.028 & 0.026 \\
\hline Total & 1350 & 1293 & 1320 & 1322 & 1285 & 3.752 & 2.532 & 3.616 \\
\hline
\end{tabular}

Table 12. Normalised decision making matrix

\begin{tabular}{|c|c|c|c|c|c|c|c|c|}
\hline & \multicolumn{8}{|c|}{ M-banking adoption factors } \\
\hline & SI & SQ & SE & $\mathrm{FC}$ & FM & $\mathrm{PR}$ & $\mathrm{PF}$ & SR \\
\hline & $\bar{x}_{1}$ & $\bar{x}_{2}$ & $\bar{x}_{3}$ & $\bar{x}_{4}$ & $\bar{x}_{5}$ & $\bar{x}_{6}$ & $\bar{x}_{7}$ & $\bar{x}_{8}$ \\
\hline Optimum direction & $\max$ & $\max$ & $\max$ & $\max$ & $\max$ & $\min$ & $\min$ & $\min$ \\
\hline Priority weights & 0.0237 & 0.0533 & 0.2019 & 0.3209 & 0.0432 & 0.1457 & 0.0656 & 0.1457 \\
\hline$a_{0}$ (optimal values) & 0.0741 & 0.0773 & 0.0758 & 0.0756 & 0.0778 & 0.2665 & 0.3949 & 0.2765 \\
\hline Akbank $\left(a_{1}\right)$ & 0.0719 & 0.0773 & 0.0758 & 0.0756 & 0.0739 & 0.2665 & 0.0987 & 0.0922 \\
\hline Aktif Yatirim Bankasi $\left(a_{2}\right)$ & 0.0459 & 0.0441 & 0.0439 & 0.0431 & 0.0444 & 0.0083 & 0.0120 & 0.0079 \\
\hline Denizbank $\left(a_{3}\right)$ & 0.0407 & 0.0379 & 0.0371 & 0.0378 & 0.0358 & 0.0067 & 0.0096 & 0.0066 \\
\hline Finansbank $\left(a_{4}\right)$ & 0.0622 & 0.0619 & 0.0621 & 0.0628 & 0.0630 & 0.0222 & 0.0263 & 0.0230 \\
\hline Garanti Bankasi $\left(a_{5}\right)$ & 0.0659 & 0.0657 & 0.0720 & 0.0688 & 0.0677 & 0.0381 & 0.0494 & 0.0395 \\
\hline Halk Bankasi $\left(a_{6}\right)$ & 0.0585 & 0.0596 & 0.0591 & 0.0582 & 0.0591 & 0.0178 & 0.0208 & 0.0184 \\
\hline $\operatorname{HSBC}\left(a_{7}\right)$ & 0.0422 & 0.0418 & 0.0394 & 0.0378 & 0.0381 & 0.0072 & 0.0107 & 0.0067 \\
\hline $\operatorname{ING}\left(a_{8}\right)$ & 0.0704 & 0.0712 & 0.0720 & 0.0741 & 0.0716 & 0.0888 & 0.0987 & 0.0922 \\
\hline Is Bankasi $\left(a_{9}\right)$ & 0.0652 & 0.0673 & 0.0644 & 0.0651 & 0.0661 & 0.0296 & 0.0359 & 0.0307 \\
\hline Odea Bank $\left(a_{10}\right)$ & 0.0496 & 0.0480 & 0.0470 & 0.0469 & 0.0475 & 0.0092 & 0.0132 & 0.0092 \\
\hline Sekerbank $\left(a_{11}\right)$ & 0.0600 & 0.0596 & 0.0606 & 0.0613 & 0.0607 & 0.0205 & 0.0232 & 0.0198 \\
\hline Sinai Kalkinma Bankasi $\left(a_{12}\right)$ & 0.0526 & 0.0518 & 0.0515 & 0.0522 & 0.0514 & 0.0111 & 0.0146 & 0.0111 \\
\hline $\operatorname{TEB}\left(a_{13}\right)$ & 0.0704 & 0.0696 & 0.0705 & 0.0703 & 0.0716 & 0.0533 & 0.0658 & 0.0691 \\
\hline Vakiflar Bankasi $\left(a_{14}\right)$ & 0.0556 & 0.0549 & 0.0545 & 0.0560 & 0.0560 & 0.0133 & 0.0165 & 0.0132 \\
\hline Yapi Kredi Bankasi $\left(a_{15}\right)$ & 0.0711 & 0.0704 & 0.0727 & 0.0734 & 0.0747 & 0.1333 & 0.0987 & 0.2765 \\
\hline Ziraat Bankasi $\left(a_{16}\right)$ & 0.0437 & 0.0418 & 0.0417 & 0.0408 & 0.0405 & 0.0076 & 0.0110 & 0.0073 \\
\hline
\end{tabular}


Table 13. Weighted normalised decision making matrix and solution results

\begin{tabular}{|c|c|c|c|c|c|c|c|c|c|c|c|}
\hline & \multicolumn{8}{|c|}{ Criteria } & \multicolumn{3}{|c|}{ Results } \\
\hline & SI & SQ & SE & FC & FM & $\mathrm{PR}$ & $\mathrm{PF}$ & SR & & & \\
\hline & $\hat{x}_{1}$ & $\hat{x}_{2}$ & $\hat{x}_{3}$ & $\hat{x}_{4}$ & $\hat{x}_{5}$ & $\hat{x}_{6}$ & $\hat{x}_{7}$ & $\hat{x}_{8}$ & S & $\mathrm{K}$ & Rank \\
\hline $\begin{array}{l}a_{0} \text { (optimal } \\
\text { values) }\end{array}$ & 0.0018 & 0.0041 & 0.0153 & 0.0243 & 0.0034 & 0.0388 & 0.0259 & 0.0403 & 0.1538 & 1 & Optimal \\
\hline Akbank $\left(a_{1}\right)$ & 0.0017 & 0.0041 & 0.0153 & 0.0243 & 0.0032 & 0.0388 & 0.0065 & 0.0134 & 0.1073 & 0.6977 & 2 \\
\hline $\begin{array}{l}\text { Aktif Yatirim } \\
\text { Bankasi }\left(a_{2}\right)\end{array}$ & 0.0011 & 0.0023 & 0.0089 & 0.0138 & 0.0019 & 0.0012 & 0.0008 & 0.0012 & 0.0312 & 0.2029 & 13 \\
\hline $\begin{array}{l}\text { Denizbank } \\
\left(a_{3}\right)\end{array}$ & 0.0010 & 0.0020 & 0.0075 & 0.0121 & 0.0015 & 0.0010 & 0.0006 & 0.0010 & 0.0267 & 0.1737 & 16 \\
\hline $\begin{array}{l}\text { Finansbank } \\
\left(a_{4}\right)\end{array}$ & 0.0015 & 0.0033 & 0.0125 & 0.0201 & 0.0027 & 0.0032 & 0.0017 & 0.0034 & 0.0485 & 0.3153 & 7 \\
\hline $\begin{array}{l}\text { Garanti } \\
\text { Bankasi }\left(a_{5}\right)\end{array}$ & 0.0016 & 0.0035 & 0.0145 & 0.0221 & 0.0029 & 0.0055 & 0.0032 & 0.0058 & 0.0592 & 0.3845 & 5 \\
\hline $\begin{array}{l}\text { Halk Bankasi } \\
\left(a_{6}\right)\end{array}$ & 0.0014 & 0.0032 & 0.0119 & 0.0187 & 0.0026 & 0.0026 & 0.0014 & 0.0027 & 0.0444 & 0.2885 & 9 \\
\hline $\operatorname{HSBC}\left(a_{7}\right)$ & 0.0010 & 0.0022 & 0.0080 & 0.0121 & 0.0016 & 0.0010 & 0.0007 & 0.0010 & 0.0277 & 0.1800 & 15 \\
\hline ING $\left(a_{8}\right)$ & 0.0017 & 0.0038 & 0.0145 & 0.0238 & 0.0031 & 0.0129 & 0.0065 & 0.0134 & 0.0797 & 0.5182 & 3 \\
\hline $\begin{array}{l}\text { Is Bankasi } \\
\left(a_{9}\right)\end{array}$ & 0.0015 & 0.0036 & 0.0130 & 0.0209 & 0.0029 & 0.0043 & 0.0024 & 0.0045 & 0.0530 & 0.3446 & 6 \\
\hline $\begin{array}{l}\text { Odea Bank } \\
\left(a_{10}\right)\end{array}$ & 0.0012 & 0.0026 & 0.0095 & 0.0150 & 0.0021 & 0.0013 & 0.0009 & 0.0013 & 0.0339 & 0.2201 & 12 \\
\hline $\begin{array}{l}\text { Sekerbank } \\
\left(a_{11}\right)\end{array}$ & 0.0014 & 0.0032 & 0.0122 & 0.0197 & 0.0026 & 0.0030 & 0.0015 & 0.0029 & 0.0465 & 0.3023 & 8 \\
\hline $\begin{array}{l}\text { Sinai } \\
\text { Kalkinma } \\
\text { Bankasi }\left(a_{12}\right)\end{array}$ & 0.0012 & 0.0028 & 0.0104 & 0.0167 & 0.0022 & 0.0016 & 0.0010 & 0.0016 & 0.0376 & 0.2442 & 11 \\
\hline $\operatorname{TEB}\left(a_{13}\right)$ & 0.0017 & 0.0037 & 0.0142 & 0.0226 & 0.0031 & 0.0078 & 0.0043 & 0.0101 & 0.0674 & 0.4383 & 4 \\
\hline $\begin{array}{l}\text { Vakiflar } \\
\text { Bankasi }\left(a_{14}\right)\end{array}$ & 0.0013 & 0.0029 & 0.0110 & 0.0180 & 0.0024 & 0.0019 & 0.0011 & 0.0019 & 0.0406 & 0.2638 & 10 \\
\hline $\begin{array}{l}\text { Yapi Kredi } \\
\text { Bankasi }\left(a_{15}\right)\end{array}$ & 0.0017 & 0.0038 & 0.0147 & 0.0235 & 0.0032 & 0.0194 & 0.0065 & 0.0403 & 0.1131 & 0.7350 & 1 \\
\hline $\begin{array}{l}\text { Ziraat } \\
\text { Bankasi }\left(a_{16}\right)\end{array}$ & 0.0010 & 0.0022 & 0.0084 & 0.0131 & 0.0017 & 0.0011 & 0.0007 & 0.0011 & 0.0294 & 0.1912 & 14 \\
\hline
\end{tabular}

According to the solution results M-banking service ranks as follows:

$$
a_{15} \succ a_{1} \succ a_{8} \succ a_{13} \succ a_{5} \succ a_{9} \succ a_{4} \succ a_{11} \succ a_{6} \succ a_{14} \succ a_{12} \succ a_{10} \succ a_{2} \succ a_{16} \succ a_{7} \succ a_{3} .
$$

Consequently, the estimation results show that the best alternative is Yapi Kredi Bankasi with a utility degree (performance ratio) of $73.5 \%$. According to Table 13, Akbank with a utility degree of $69.77 \%$ is the second ranking M-banking service. ING Bank with a utility degree of $51.82 \%$ is the third ranking M-banking service in Turkey. Finally, TEB and Garanti Bankasi with utility degrees of $43.83 \%$ and $38.45 \%$, respectively, are selected as 
the fourth and fifth choices for M-banking services. However, Ziraat Bankasi, HSBC, and Denizbank with utility degrees of $19.12 \%, 18 \%$ and $17.37 \%$, respectively, are the worst Mbanking services.

In the present study, a sensitivity analysis is applied to show how the rank order of Mbanking services behaves when the priority weights of the criteria are changed. To do this, the priority weights are changed for two criteria while the others are constant. For example, the priority weight of the $S I$ is changed with $S Q, S E, F C$ and so on, sequentially, while the others are constant. Table 14 shows the cases that considered. Whilst the priority weights are changing mutually, the utility value of alternatives is changing. In Case 1, if SI and SQ's priority weights are exchanged, then the utility value of $a_{15}$ arises from 0.735 to 0.736 and $a_{1}$ falls from 0.698 to 0.697 . Hence, the preference ranking of $a_{15}$ does not change except Case 7. Besides, $P_{3}$ is determined to be the best alternative in all cases except Case 7 as to the sensitivity analysis results since it has maximum utility value after the priority weight exchanges realized here.

Table 14. The sensitivity analysis results

\begin{tabular}{|c|c|c|c|c|c|c|c|c|c|c|c|c|c|c|c|c|c|}
\hline \multirow{2}{*}{$\begin{array}{l}\mathrm{Ca}- \\
\text { ses }\end{array}$} & \multirow[t]{2}{*}{ Variables } & \multicolumn{16}{|c|}{ Alternatives } \\
\hline & & $a_{1}$ & $a_{2}$ & $a_{3}$ & $a_{4}$ & $a_{5}$ & $a_{6}$ & $a_{7}$ & $a_{8}$ & $a_{9}$ & $a_{10}$ & $a_{11}$ & $a_{12}$ & $a_{13}$ & $a_{14}$ & $a_{15}$ & $a_{16}$ \\
\hline \multirow[t]{2}{*}{1} & $\mathrm{~K}$ & 0.697 & 0.203 & 0.174 & 0.316 & 0.385 & 0.288 & 0.180 & 0.518 & 0.344 & 0.221 & 0.303 & 0.244 & 0.439 & 0.264 & 0.736 & 0.192 \\
\hline & Ranking & 2 & 13 & 16 & 7 & 5 & 9 & 15 & 3 & 6 & 12 & 8 & 11 & 4 & 10 & 1 & 14 \\
\hline \multirow[t]{2}{*}{2} & $\mathrm{~K}$ & 0.694 & 0.206 & 0.178 & 0.316 & 0.378 & 0.288 & 0.184 & 0.517 & 0.346 & 0.224 & 0.302 & 0.246 & 0.439 & 0.265 & 0.735 & 0.194 \\
\hline & Ranking & 2 & 13 & 16 & 7 & 5 & 9 & 15 & 3 & 6 & 12 & 8 & 11 & 4 & 10 & 1 & 14 \\
\hline \multirow[t]{2}{*}{3} & K & 0.692 & 0.209 & 0.180 & 0.315 & 0.380 & 0.290 & 0.189 & 0.513 & 0.346 & 0.226 & 0.301 & 0.246 & 0.440 & 0.264 & 0.733 & 0.197 \\
\hline & Ranking & 2 & 13 & 16 & 7 & 5 & 9 & 15 & 3 & 6 & 12 & 8 & 11 & 4 & 10 & 1 & 14 \\
\hline \multirow[t]{2}{*}{4} & $\mathrm{~K}$ & 0.698 & 0.203 & 0.174 & 0.315 & 0.384 & 0.289 & 0.181 & 0.518 & 0.345 & 0.220 & 0.302 & 0.244 & 0.438 & 0.264 & 0.735 & 0.192 \\
\hline & Ranking & 2 & 13 & 16 & 7 & 5 & 9 & 15 & 3 & 6 & 12 & 8 & 11 & 4 & 10 & 1 & 14 \\
\hline \multirow[t]{2}{*}{5} & K & 0.641 & 0.275 & 0.237 & 0.410 & 0.480 & 0.379 & 0.245 & 0.594 & 0.440 & 0.298 & 0.394 & 0.327 & 0.533 & 0.351 & 0.809 & 0.259 \\
\hline & Ranking & 2 & 13 & 16 & 7 & 5 & 9 & 15 & 3 & 6 & 12 & 8 & 11 & 4 & 10 & 1 & 14 \\
\hline \multirow[t]{2}{*}{6} & K & 0.756 & 0.232 & 0.200 & 0.356 & 0.426 & 0.327 & 0.207 & 0.559 & 0.386 & 0.252 & 0.342 & 0.279 & 0.482 & 0.301 & 0.797 & 0.219 \\
\hline & Ranking & 2 & 13 & 16 & 7 & 5 & 9 & 15 & 3 & 6 & 12 & 8 & 11 & 4 & 10 & 1 & 14 \\
\hline \multirow[t]{2}{*}{7} & K & 0.812 & 0.278 & 0.239 & 0.413 & 0.483 & 0.382 & 0.248 & 0.597 & 0.443 & 0.300 & 0.398 & 0.330 & 0.523 & 0.354 & 0.682 & 0.262 \\
\hline & Ranking & 1 & 13 & 16 & 7 & 5 & 9 & 15 & 3 & 6 & 12 & 8 & 11 & 4 & 10 & 2 & 14 \\
\hline
\end{tabular}

\section{Discussion and limitations}

In this study, criteria weights are determined by applying the FAHP method. In order to rank M-banking service alternatives and select the best M-banking service, the ARAS method is used to evaluate alternatives.

As this study has shown, facilitating condition (FC) is the most important factor effecting M-banking adoption. The results of this study are also consistent with the findings of previous studies (Lee, Chung 2009; Püschel et al. 2010; Zhou et al. 2010). This demonstrates that when clients perceive they are able to use M-banking and mobile devices that 
are available to them, the more likely it is they will continue using M-banking. This also means, in Turkey, fundamental necessities for use of M-banking are satisfied. Therefore, it is suggested that clients should be provided adequate information related to M-banking and its advantages.

The next factor affecting M-banking adoption is self-efficacy (SE). Püschel et al. (2010) indicates that self-efficacy is one of the most important factors influencing the client to adopt M-banking. Furthermore, self-efficacy is also an important M-banking adoption factor in Luarn and Lin's (2005) study. They stated that the total effect of self-efficacy on behavioral intention was 0.54 . Hence, bank managers, owners, and practitioners should focus on constructing of self-efficacy.

The third and fourth factors in the adoption of M-banking are privacy risk (PR) and security risk (SR). Clients perceive these factors as substantial barriers to the adoption of the M-banking services. In other words, the higher the perception of privacy risk and security risk of M-banking services, the less clients intend to use this new channel. Banks should therefore address the risk concern to ensure that their commercial transactions are safe and that the whole M-banking service is operable (Chen 2013). In addition, privacy risk and security risk have been examined in M-banking adoption related studies. This is consistent with extant literature, which has shown privacy risk and security risk to have a strong positive relationship with behavioral intentions (Lee et al. 2007; Laukkanen, Cruz 2008; Koenig-Lewis et al. 2010; Wessels, Drennan 2010; Negash 2011; Akturan, Tezcan 2012; Chen 2013).

Another factor affecting M-banking adoption is their performance risk (PF) which is determined as the fifth factor in this study. This result confirms Zhou's (Zhou et al. 2010) and Chen's (Chen 2013) studies that performance risk as one of the key barriers for M-banking adoption. As a result, the extent to which if a person believes that an M-banking service is not meeting the requirements (i.e. download speed, transaction time, etc.) of him/her, he or she will not disposed to use it. In this context, it is suggested that M-banking systems are designed in a way so that they can be increased performance risk and can be used confidingly different clients. To do this, decreasing in performance risk should be promoted resolutely by bank practitioners. Thus, the more customers believe the M-banking service performing poorly, the less they are likely to use and adopt it.

The next factor affecting M-banking adoption is system quality (SQ). Consistent with other studies (Gu et al. 2009; Negash 2011), system quality affects continuing to use. For instance, Gu et al.'s (2009) study recommends that system quality has rather important on clients' continuing to use M-banking in Korea. Accordingly, system quality impacts not only adoption behavior, but also customer satisfaction. If the M-banking services are reliable, flexible, accessible, accurate and speedy, clients will perceive them to be useful.

According to the findings, familiarity (FM) is found as a seventh factor in the M-banking adoption. In $\mathrm{Gu}$ et al.'s (2009) study, the hypothesis that familiarity positively affects perceived ease of use has been confirmed. This indicates that clients will perceive it to be easy to use since they are familiar with M-banking services. Consequently, thanks to prior experience, familiarity increases the continuing to use M-banking services.

Finally, social influence (SI) is found as an eighth factor in M-banking adoption. In Zhou's et al. (2010) study, social influence has significant effects on user adoption. In ad- 
dition, these findings are in parallel with the study of Bidar's et al. (2014) study. Hence, Turkish clients may be influenced by new advertising methods, their society, and social networks and these interactions can lead their decisions.

The case study also shows that the proposed model is simple and proper to solve complex M-banking problems. Application of the FAHP and the ARAS combination revealed that the best M-banking service is Yapi Kredi Bankasi. Furthermore, the proposed FAHP\&ARAS model indicates the performance ratio of each M-banking service alternative to the optimal M-banking service alternative. The performance of Yapi Kredi Bankasi nearly achieves $74 \%$ of the performance of the optimal M-banking service.

There are some limitations in this study. First of all, the adoption factors of M-banking services were determined from the literature review under the supervision of the decision making team. Hence, it may exclude some possible adoption factors. In future research, different M-banking adoption factors can be used to evaluate M-banking services. Second, this study focuses on Turkey, which is a developing economy compared with some others. Future research can evaluate M-banking services in developed countries with relatively mature M-banking. This may better insights on M-banking situation around the world. Finally, future research efforts can utilize alternate MCDM techniques, such as TOPSIS, ANP, SAW, MOORA, MULTIMOORA, WASPAS, TODIM, COPRAS, COPRAS-G, and VIKOR to evaluate M-banking services.

\section{Conclusions}

Nowadays, M-banking has ceased to be an alternative distribution channel and become the main channel. Hence, M-banking users view M-banking as a necessity not as an extra service. Moreover, they are expected to improve the quality of service from their banks.

Banks invested in M-banking previously have expanded their investments thanks to rapidly rising user numbers in M-banking. Banks not invested in it, on the other hand, are directed to step into this new channel. In Turkey, considering nearly one fifth of transactions conducted in 16 banks via mobile, it is clear that banks which are extending the mobile transaction sets will increase their mobile share. Unfortunately, other banks will not get a share of the market and fell back in the competition. M-banking users expect from banks to increase the quality of service. Banks which are realizing customer expectations in this process and working in this direction will provide a competitive advantage.

The realistic modeling of many business problems requires to consider the conflicting opinions of decision makers, the existence of multiple criteria, the complex and subjective nature of the evaluation process. Multi criteria evaluation, therefore, contributes in the business area via the determination of priority weights, via the selection of the suitable alternative, and the disclosure of the choices in the decision making process. Above all, aggregating both qualitative and quantitative decision criteria in the evaluation process, analyzing and solving complex problems easily, making reliable decisions, and allowing decision makers to choose the best alternative in the process of decision making are the main advantages of ARAS as a MCDM method. Therefore, ARAS method is preferred to form this proposed integrated model. 
Overall, M-banking services of 16 banks which are serving branch property in Turkey are evaluated by FAHP and ARAS integrated model. First, significance of expert estimations is evaluated with the help of the FAHP method. This means the use of proposed model allows considering opinions of all decision making team members in the decision making process. Then, the ARAS method is applied for determination of the best M-banking service. In the present study, the priority weights of factors affecting the M-banking adoption are determined in the context of Turkey. When the results are analyzed, it can obviously be seen that facilitating conditions, self-efficacy, privacy risk, and security risk are the most important factors of M-banking adoptions. It means that perceived ease of use is found as the most important dimension affecting M-banking adoption and it should be paid more attention and should be continuously improved. Ranking results stated that the best M-banking service in Turkey is Yapi Kredi Bankasi. However, Denizbank is found to have the worst M-banking service.

In spite of working with a decision making team provides some advantages, it requires a coordinated act which can require great effort. Thereby, fuzzy numbers are utilized in AHP to avoid uncertainties in group decision making. The proposed model gives reliable and robust results. M-banking adoption factors obtained by literature review and decision making team, are used, which means that the proposed model can be used for similar studies. Nevertheless, modification in evaluating factors may be required for different sectors.

In conclusion, the proposed model builds a new simple and hierarchical structure approach to evaluate M-banking services and select the best service. This novel model not only increases the efficiency of the M-banking services, it also reduces the time taken by bank managers and clients to gather experience and knowledge in the evaluation of an M-banking service. In sum, it helps to overcome difficulties in M-banking service evaluation process and increases the efficiency of the M-banking service activities. Hence, the proposed model has a great future in the banking sector and business field. Additionally, this novel model would use other electronic banking channels smoothly. In terms of future research, the proposed model could be performed different sectors by revision of factors. Finally, various approaches for determining weights (SWARA, entropy, eigenvector method, expert method, etc.) may be employed instead of the FAHP to calculate the priority weights in evaluation and selection process.

\section{References}

Aghdaie, M. H.; Hashemkhani Zolfani, S.; Zavadskas, E. K. 2013. Market segment evaluation and selection based on application of fuzzy AHP and COPRAS-G methods, Journal of Business Economics and Management 14(1): 213-233. https://doi.org/10.3846/16111699.2012.721392

Akturan, U.; Tezcan, N. 2012. Mobile banking adoption of the youth market: perceptions and intentions, Marketing Intelligence and Planning 30(4): 444-459. https://doi.org/10.1108/02634501211231928

Aliakbari Nouri, F.; Khalili Esbouei, S.; Antucheviciene, J. 2015. A hybrid MCDM approach based on fuzzy ANP and fuzzy TOPSIS for technology selection, Informatica 26(3): 369-388. https://doi.org/10.15388/Informatica.2015.53

Bakshi, T.; Sarkar, B. 2011. MCA based performance evaluation of project selection, International Journal of Software Engineering and Applications 2(2): 14-22. https://doi.org/10.5121/ijsea.2011.2202

Baležentis, A.; Štreimikienė, D. 2013. Integrated sustainability index: the case study of Lithuania, Intellectual Economics 7(3): 289-303. https://doi.org/10.13165/IE-13-7-3-02 
Baležentis, A.; Baležentis, T.; Misiunas, A. 2012. An integrated assessment of Lithuanian economic sectors based on financial ratios and fuzzy MCDM methods, Technological and Economic Development of Economy 18(1): 34-53. https://doi.org/10.3846/20294913.2012.656151

BAT (Banks Association of Turkey). 2015. Statistical reports [online], [cited 2 October 2015]. Available from Internet: https://www.tbb.org.tr/en/banks-and-banking-sector-information/statisticalreports $/ 20$

Bidar, R.; Fard, M. B.; Salman, Y. B.; Tunga, M. A.; Cheng, H. I. 2014. Factors affecting the adoption of mobile banking: sample of Turkey, in 16th International Conference on Advanced Communication Technology (ICACT), 16-19 February 2014, Phoenix Park, PyeongChang, Korea (South), 1278-1282. https://doi.org/10.1109/ICACT.2014.6779165

Bilsel, R. U.; Büyükozkan, G.; Ruan, D. 2006. A fuzzy preference-ranking model for a quality evaluation of hospital web sites, International Journal of Intelligent Systems 21: 1181-1197. https://doi.org/10.1002/int.20177

Bulut, E.; Duru, O.; Keçeci, T.; Yoshida, S. 2012. Use of consistency index, expert prioritization and direct numerical inputs for generic fuzzy-AHP modeling: a process model for shipping asset management, Expert Systems with Applications 39(2): 1911-1923. https://doi.org/10.1016/j.eswa.2011.08.056

Calabrese, A.; Costa, R.; Menichini, T. 2013. Using fuzzy AHP to manage intellectual capital assets: an application to the ICT service industry, Expert Systems with Applications 40(9): 3747-3755. https://doi.org/10.1016/j.eswa.2012.12.081

Calabrese, A.; Costa, R.; Levialdi, N.; Menichini, T. 2016. A fuzzy Analytic Hierarchy Process method to support materiality assessment in sustainability reporting, Journal of Cleaner Production 121: 248-264. https://doi.org/10.1016/j.jclepro.2015.12.005

Canzano, D.; Grimaldi, M. 2012. An integrated framework to implement a knowledge management programme: the role of technological tools and techniques, International Journal of Intelligent Enterprise 1(3/4): 233-247. https://doi.org/10.1504/IJIE.2012.052554

Chan, F. T. S.; Kumar, N. 2007. Global supplier development considering risk factors using fuzzy extended AHP based approach, Omega 35: 417-431. https://doi.org/10.1016/j.omega.2005.08.004

Chang, D. Y. 1992. Extent analysis and synthetic decision, Optimization Techniques and Applications 1(1): 352-355.

Chang, D. Y. 1996. Applications of the extent analysis method on fuzzy AHP, European Journal of Operational Research 95: 649-655. https://doi.org/10.1016/0377-2217(95)00300-2

Chatterjee, P.; Chakraborty, S. 2013. Gear material selection using complex proportional assessment and additive ratio assessment-based approaches: a comparative study, International Journal of Materials Science and Engineering 1(2): 104-111. https://doi.org/10.12720/ijmse.1.2.104-111

Chen, C. 2013. Perceived risk, usage frequency of mobile banking services, Managing Service Quality 23(5): 410-436. https://doi.org/10.1108/MSQ-10-2012-0137

Chen, L. Y.; Wang, T. C. 2009. Optimizing partners' choice in IS/IT outsourcing projects: the strategic decision of fuzzy VIKOR, International Journal of Production Economics 120(1): 233-242. https://doi.org/10.1016/j.ijpe.2008.07.022

Chou, W. C.; Cheng, Y. P. 2012. A hybrid fuzzy MCDM approach for evaluating website quality of professional accounting firms, Expert Systems with Applications 39(3): 2783-2793. https://doi.org/10.1016/j.eswa.2011.08.138

Crabbe, M.; Standing, C.; Standing, S.; Karjaluoto, H. 2009. An adoption model for mobile banking in Ghana, International Journal of Mobile Communications 7(5): 515-543. https://doi.org/10.1504/IJMC.2009.024391

Cruz, P.; Neto, L. N. F.; Munoz-Gallego, P.; Laukkanen, T. 2010. Mobile banking rollout in emerging markets: evidence from Brazil, International Journal of Bank Marketing 28(5): 342-371. https://doi.org/10.1108/02652321011064881 
Dadelo, S.; Turskis, Z.; Zavadskas, E. K.; Dadeliene, R. 2012. Multiple criteria assessment of elite security personal on the basis of ARAS and expert methods, Economic Computation and Economic Cybernetics Studies and Research 46(4): 65-88.

Das, M. C.; Sarkar, B.; Ray, S. 2012. A framework to measure relative performance of Indian technical institutions using integrated fuzzy AHP and COPRAS methodology, Socio-Economic Planning Sciences 46(3): 230-241. https://doi.org/10.1016/j.seps.2011.12.001

Davis, F. D. 1989. Perceived usefulness, perceived ease of use, and user acceptance of information technology, MIS Quarterly 13(3): 319-340. https://doi.org/10.2307/249008

DeLone, W. H.; McLean, E. R. 2003. The DeLone and McLean model of information systems success: a ten-year update, Journal of Management Information Systems 19(4): 9-30.

Ecer, F. 2014. A hybrid banking websites quality evaluation model using AHP and COPRAS-G: a Turkey case, Technological and Economic Development of Economy 20(4): 758-782. https://doi.org/10.3846/20294913.2014.915596

Ecer, F. 2015. Performance evaluation of internet banking branches via a hybrid MCDM model under fuzzy environment, Economic Computation and Economic Cybernetics Studies and Research 49(2): 211-230.

Ecer, F. 2016. ARAS Yöntemi Kullanılarak Kurumsal Kaynak Planlaması Yazılımı Seçimi, Uluslararası Alanya İşletme Fakültesi Dergisi 8(1): 89-98.

Fishbein, M.; Ajzen, I. 1975. Attitude, intention and behavior: An introduction to theory and research. Washington: Addison-Wesley, 578 p.

Gu, J. C.; Lee, S. C.; Suh, Y. H. 2009. Determinants of behavioral intention to mobile banking, Expert Systems with Applications 36(9): 11605-11616. https://doi.org/10.1016/j.eswa.2009.03.024

Hanafizadeh, P.; Behboudi, M.; Abedini Koshksaray, A.; Jalilvand Shirkhani Tabar, M. 2014. Mobilebanking adoption by Iranian bank clients, Telematics and Informatics 31(1): 62-78.

https://doi.org/10.1016/j.tele.2012.11.001

Hoehle, H.; Scornavacca, E.; Huff, S. 2012. Three decades of research on consumer adoption and utilization of electronic banking channels: a literature analysis, Decision Support Systems 54(1): 122-132. https://doi.org/10.1016/j.dss.2012.04.010

Kahraman, C.; Cebeci, U.; Ruan, D. 2004. Multi-attribute comparison of catering service companies using fuzzy AHP: the case of Turkey, International Journal of Production Economics 87: 171-184. https://doi.org/10.1016/S0925-5273(03)00099-9

Kim, G.; Shin, B.; Lee, H. G. 2009. Understanding dynamics between initial trust and usage intentions of mobile banking, Information Systems Journal 19(3): 283-311. https://doi.org/10.1111/j.1365-2575.2007.00269.x

Koenig-Lewis, N.; Palmer, A.; Moll, A. 2010. Predicting young consumers' take up of mobile banking services, International Journal of Bank Marketing 28 (5): 410-432. https://doi.org/10.1108/02652321011064917

Korsgaard, M. A.; Schweiger, D. M.; Sapienza, H. J. 1995. Building commitment, attachment, and trust in strategic decision-making teams: the role of procedural justice, Academy of Management Journal 38(1): 60-84. https://doi.org/10.2307/256728

Kutut, V.; Zavadskas, E. K.; Lazauskas, M. 2013. Assessment of priority options for preservation of historic city centre buildings using MCDM (ARAS), Procedia Engineering 57: 657-661. https://doi.org/10.1016/j.proeng.2013.04.083

Laarhoven, P. J. M.; Pedrycz, W. 1983. A fuzzy extension of Saaty's priority theory, Fuzzy Sets and Systems 11: 229-241. https://doi.org/10.1016/S0165-0114(83)80082-7

Laukkanen, T.; Cruz, P. 2008. Barriers to mobile banking adoption: a cross-national study, Proceedings of the International Conference on E-Business - Volume 1: ICE-B, 26-29 July 2008, Porto, Portugal, 300-306.

Laukkanen, T. 2007. Internet vs mobile banking comparing customer value perceptions, Business Process Management Journal 13(6): 788-797. https://doi.org/10.1108/14637150710834550 
Lee, K. C.; N. Chung. 2009. Understanding factors affecting trust in and satisfaction with mobile banking in Korea: a modified Delone and Mclean's Model perspective, Interacting with Computers 21: 385-392. https://doi.org/10.1016/j.intcom.2009.06.004

Lee, K. S.; Lee, H. S.; Kim, S. Y. 2007. Factors influencing the adoption behavior of mobile banking: a South Korean perspective, Journal of Internet Banking and Commerce 12(2): 1-9.

Leung, L. C.; Cao, D. 2000. On consistency and ranking of alternatives in fuzzy AHP, European Journal of Operational Research 124(1): 102-113. https://doi.org/10.1016/S0377-2217(99)00118-6

Lin, H. F. 2011. An empirical investigation of mobile banking adoption: the effect of innovation attributes and knowledge-based trust, International Journal of Information Management 31(3): 252-260. https://doi.org/10.1016/j.ijinfomgt.2010.07.006

Lu, J.; Yu, C. S.; Liu, C.; Yao, J. E. 2003. Technology acceptance model for wireless internet, Internet Research 13(3): 206-222. https://doi.org/10.1108/10662240310478222

Luarn, P.; Lin, H. 2005. Toward an understanding of the behavioral intention to use mobile banking, Computers in Human Behavior 21: 873-891. https://doi.org/10.1016/j.chb.2004.03.003

Medineckiene, M.; Zavadskas, E. K.; Björk, F.; Turskis, Z. 2015. Multi-criteria decision-making system for sustainable building assessment/certification, Archives of Civil and Mechanical Engineering 15(1): 11-18. https://doi.org/10.1016/j.acme.2014.09.001

Mikhailov, L. 2003. Deriving priorities from fuzzy pairwise comparison judgments, Fuzzy Sets and Systems 134: 365-385. https://doi.org/10.1016/S0165-0114(02)00383-4

Negash, S. 2011. Mobile banking adoption by under-banked communities in the United States: adapting mobile banking features from low-income countries, in 11th International Conference on Mobile Business (ICMB), 20-21 June 2011, Como, Italy, 205-209.

Peevers, G.; Douglas, G.; Jack, M. A. 2008. A usability comparison of three alternative message formats for an SMS banking service, International Journal of Human-Computer Studies 66(2): 113-123. https://doi.org/10.1016/j.ijhcs.2007.09.005

Püschel, J.; Mazzon, J. A.; Hernandez, J. M. C. 2010. Mobile banking: proposition of an integrated adoption intention framework, International Journal of Bank Marketing 28(5): 389-409. https://doi.org/10.1108/02652321011064908

Reza, S.; Majid, A. 2013. Ranking financial institutions based on of trust in online banking using ARAS and ANP method, International Research Journal of Applied and Basic Sciences 6(4): 415-423.

Riivari, J. 2005. Mobile banking: a powerful new marketing and CRM tool for financial services companies all over Europe?, Journal of Financial Services Marketing 10(1): 11-20. https://doi.org/10.1057/palgrave.fsm.4770170

Riquelme, H. E.; Rios, R. E. 2010. The moderating effect of gender in the adoption of mobile banking, International Journal of Bank Marketing 28(5): 328-341. https://doi.org/10.1108/02652321011064872

Saaty, T. L. 1980. The analytic hierarchy process. New York: McGraw Hill, $287 \mathrm{p}$

Singh, S.; Srivastava, V.; Srivastava, R. K. 2010. Customer acceptance of mobile banking: a conceptual framework, SIES Journal of Management 7(1): 55-64.

Sliogeriene, J.; Turskis, Z.; Streimikiene, D. 2013. Analysis and choice of energy generation technologies: the multiple criteria assessment on the case study of Lithuania, Energy Procedia 32: 11-20. https://doi.org/10.1016/j.egypro.2013.05.003

Sušinskas, S.; Zavadskas, E. K.; Turskis, Z. 2011. Multiple criteria assessment of pile-columns alternatives, The Baltic Journal of Road and Bridge Engineering 6(3): 77-83. https://doi.org/10.3846/bjrbe.2011.19

Tavana, M.; Momeni, E.; Rezaeiniya, N.; Mirhedayatian, S. M.; Rezaeiniya, H. 2013. A novel hybrid social media platform selection model using fuzzy ANP and COPRAS-G, Expert Systems with Applications 40(14): 5694-5702. https://doi.org/10.1016/j.eswa.2013.05.015 
Tupenaite, L.; Zavadskas, E. K.; Kaklauskas, A.; Turskis, Z.; Seniut, M. 2010. Multiple criteria assessment of alternatives for built and human environment renovation, Journal of Civil Engineering and Management 16(2): 257-266. https://doi.org/10.3846/jcem.2010.30

Venkatesh, V. 2000. Determinants of perceived ease of use: integrating control, intrinsic motivation, and emotion into the technology acceptance model, Information System Research 11(4): 342-365. https://doi.org/10.1287/isre.11.4.342.11872

Wang, Y. M.; Luo, Y.; Hua, Z. 2008. On the extent analysis method for fuzzy AHP and its applications, European Journal of Operational Research 186(2): 735-747. https://doi.org/10.1016/j.ejor.2007.01.050

Wang, Y. M.; Chin, K. S. 2011. Fuzzy analytic hierarchy process: A logarithmic fuzzy preference programming methodology, International Journal of Approximate Reasoning 52: 541-553. https://doi.org/10.1016/j.ijar.2010.12.004

Wessels, L.; Drennan, J. 2010. An investigation of consumer acceptance of M-banking, International Journal of Bank Marketing 28(7): 547-568. https://doi.org/10.1108/02652321011085194

Zadeh, L. A. 1965. Fuzzy set, Information Control 18(2): 338-353. https://doi.org/10.1016/S0019-9958(65)90241-X

Zamani, M.; Rabbani, A.; Yazdani-Chamzini, A.; Turskis, Z. 2014. An integrated model for extending brand based on fuzzy ARAS and ANP methods, Journal of Business Economics and Management 15(3): 403-423. https://doi.org/10.3846/16111699.2014.923929

Zavadskas E. K.; Turskis Z. 2010. A new additive ratio assessment (ARAS) method in multicriteria decision-making, Technological and Economic Development of Economy 16(2): 159-172. https://doi.org/10.3846/tede.2010.10

Zavadskas, E. K.; Turskis, Z.; Vilutiene, T. 2010. Multiple criteria analysis of foundation instalment alternatives by applying Additive Ratio Assessment (ARAS) method, Archives of Civil and Mechanical Engineering 10(3): 123-141. https://doi.org/10.1016/S1644-9665(12)60141-1

Zavadskas, E. K.; Vainiūnas, P.; Turskis, Z.; Tamošaitienė, J. 2012. Multiple criteria decision support system for assessment of projects managers in construction, International Journal of Information Technology and Decision Making 11(2): 501-520. https://doi.org/10.1142/S0219622012400135

Zavadskas, E. K.; Vilutiene, T.; Turskis, Z.; Saparauskas, J. 2014. Multi-criteria analysis of projects' performance in construction, Archives of Civil and Mechanical Engineering 14(1): 114-121. https://doi.org/10.1016/j.acme.2013.07.006

Zhou, T. 2012. Examining mobile banking user adoption from the perspectives of trust and flow experience, Information Technology and Management 13(1): 27-37. https://doi.org/10.1007/s10799-011-0111-8

Zhou, T.; Lu, Y.; Wang, B. 2010. Integrating TTF and UTAUT to explain mobile banking user adoption, Computers in Human Behavior 26(4): 760-767. https://doi.org/10.1016/j.chb.2010.01.013

Zhu, K. J.; Jing, Y.; Chang, D. Y. 1999. A discussion on extent analysis method and applications of fuzzy AHP, European Journal of Operational Research 116(2): 450-456.

https://doi.org/10.1016/S0377-2217(98)00331-2

Fatih ECER is an Associate Professor of Operations Research in the Business administration, Faculty of Economics and Business Administrations, University of Afyon Kocatepe, Turkey. He holds a BSc in Mathematics from Dokuz Eylul University, Izmir, Turkey, and a MSc and PhD in Business Administrations from University of Afyon Kocatepe, Turkey. His work has been published, or is forthcoming, in high quality international journals. His current research interests are in the Multiple Criteria Decision Making (MCDM), optimization, Artificial Intelligence, and data mining. 